\title{
Sprawozdanie z III edycji Diabetes Research School w Sztokholmie
}

W dniach 13-14 września 2015 roku w Sztokholmie, na dwa dni przed 51. Zjazdem Europejskiego Towarzystwa Badań nad Cukrzycą (EASD, European Association for the Study of Diabetes), odbyło się już trzecie spotkanie Diabetes Research School organizowane przez Niemieckie Centrum Badań nad Cukrzycą (DZD, Deutsches Zentrum für Diabetesforschung). W kursie wzięło udział 86 uczestników z 19 krajów. Poza mną było jeszcze 2 uczestników z Polski. Zostaliśmy zakwaterowani w zabytkowym hotelu Hasselbacken na wyspie Djurgarden, która słynie z pięknych terenów parkowych. Na jej obszarze znajdują się między innymi Muzeum Vasa, Muzeum Nordyckie oraz historyczny Skansen.

Kurs rozpoczął się od wystąpienia Profesora Hansa Ulricha Häringa, członka zarządu DZD. Tego dnia wysłuchaliśmy 2 znakomitych wykładów. Pierwszy z nich na temat roli tkanki tłuszczowej w insulinooporności wygłosił profesor Ulf Smith z Uniwersytetu w Göteborgu. Od niedawna wiadomo, że adipocyty to nie tylko komórki magazynujące energię w postaci tłuszczu, ale czynny endokrynnie organ produkujący hormony, cytokiny i czynniki wzrostu. Przyrost masy ciała z towarzyszącym wzrostem masy tkanki tłuszczowej prowadzi do nadprodukcji wymienionych substancji i zaburzenia wielu procesów. Skutkuje to między innymi rozwojem cukrzycy typu 2 oraz chorób układu sercowo-naczyniowego i nowotworów.

Drugi wykład na temat roli brązowej tkanki tłuszczowej w etiopatogenezie otyłości przedstawiła Profesor Barbara Cannon z Uniwersytetu w Sztokhol-

Adres do korespondencji: lek. Melania Mikołajczyk

Klinika Chorób Wewnętrznych,

Diabetologii i Farmakologii Klinicznej

Uniwersytet Medyczny w Łodzi

e-mail: melania.mikolajczyk@umed.lodz.pl

Diabetologia Kliniczna 2015, tom 4, 5, 218-219

DOI: $10.5603 /$ DK.2015.0026

Nadesłano: 15.11.2015

Przyjęto do druku: 23.11.2015 mie, Prezes Królewskiej Szwedzkiej Akademii Nauk. Brązowa tkanka tłuszczowa pośredniczy w rozpraszaniu energii i utylizacji glukozy, a tym samym przyczynia się do zachowania równowagi energetycznej. Obniżenie masy i/lub zaburzenia funkcjonowania brązowej tkanki tłuszczowej sprzyjają rozwojowi otyłości i zaburzeniom metabolizmu glukozy. Poznanie mechanizmów aktywacji lub odnawiania brązowej tkanki tłuszczowej może przyczynić się w przyszłości do powstania skutecznych metod leczenia otyłości i jej powikłań.

Wieczorem zwiedzaliśmy pobliski skansen. Hasłem przewodnim wycieczki było „Zdrowie i choroby w przeszłości". Po zwiedzaniu zostaliśmy zaproszeni na uroczystą kolację.

Drugiego dnia wysłuchaliśmy kolejnych wykładów o bardzo wysokim poziomie merytorycznym. Pierwszy dotyczący dysfunkcji komórki beta w cukrzycy typu 2 wygłosił Profesor Claes Wollheim z Uniwersytetu w Genewie. Wykładowca poświęcił wiele uwagi roli mitochondriów w komórkach beta trzustki. Prawidłowo funkcjonujące kanały wapniowe w mitochondriach odgrywają ważną rolę w procesie wytwarzaniu gradientu pH i wydzielania insuliny. Mitochondrialny stres oksydacyjny i hiperfosfatemia mogą zaś upośledzać wydzielanie insuliny i przyczyniać się do apoptozy komórek. Profesor zwracał także uwagę na problem gromadzenia ubikwityny oraz zmniejszenia aktywności proteasomów w komórkach beta trzustki osób chorych na cukrzycę.

Profesor Patrik Rorsman, z Uniwersytetu w Oksfordzie podjął temat roli glukagonu jako niedocenianego hormonu w patofizjologii cukrzycy. Nadprodukcja glukagonu przez komórki alfa nasila między innymi inulinooporność, co w konsekwencji pogarsza funkcję komórek beta wysp trzustkowych. W ten sposób zachodzą cykliczne zmiany patologiczne, nasilające zaburzenia metabolizmu glukozy. Profesor podkreślał także znaczenie somatostatyny - hormonu hamującego wydzielanie glukagonu i insuliny. Obecnie trwają badania nad możliwością łącznego stosowania insuliny 


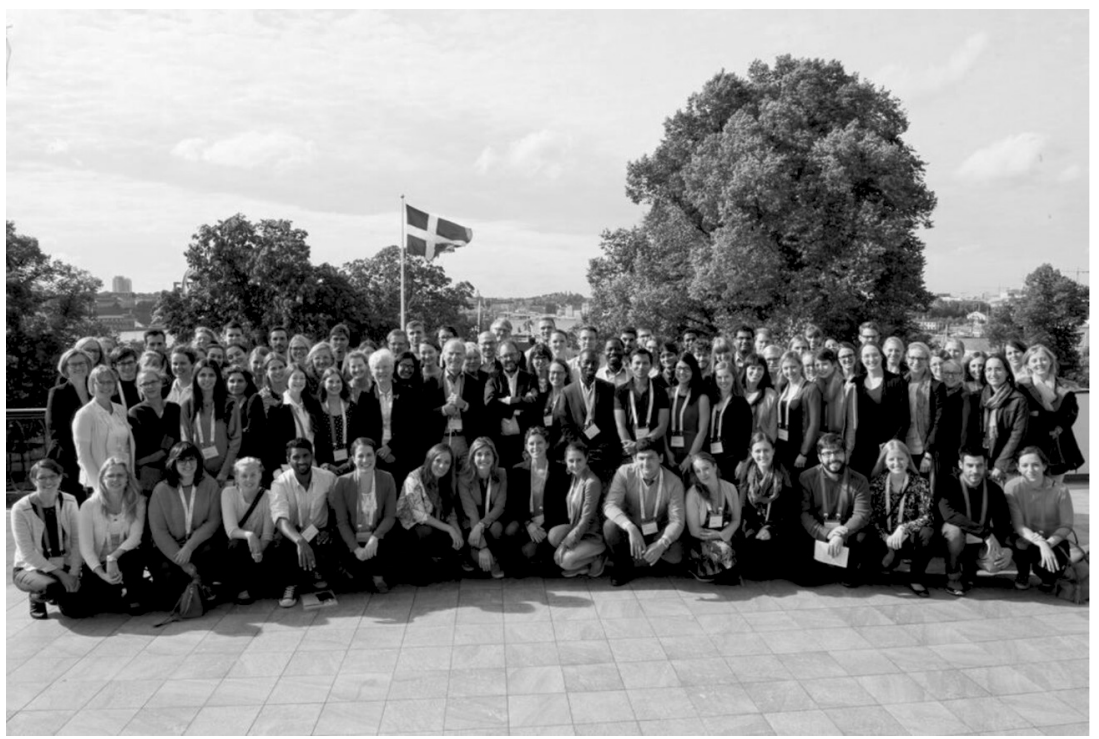

Na zdjęciu uczestnicy Diabetes Research School wraz z wykładowcami

i somatostatyny w celu zmniejszenia ryzyka hipoglikemii.

Wystąpienie Doktora Philipa Larsena, przedstawiciela firmy Sanofi, było poświęcone innowacyjnym rozwiązaniom przemysłu farmaceutycznego w leczeniu cukrzycy, wykorzystującym związki, które pozwoliłyby zahamować apoptozę komórek beta trzustki i tym samym zmniejszyć częstość stosowania lub całkowicie wyeliminować iniekcje z insuliny. Hormon ten, jak wiadomo, oprócz wielu działań korzystnych wiąże się również z działaniami niepożądanymi. Alternatywą w leczeniu cukrzycy, zwłaszcza typu 1, wydają się komórki macierzyste. Wyniki pierwszych terapii eksperymentalnych są bardzo obiecujące.

Profesor Leif Groop z Uniwersytetu w Malmö zajął stanowisko wobec ważnego pytania - czy wyniki badań genetycznych w cukrzycy przekładają się na praktykę kliniczną? Choć wniosek z wykładu był taki, że genetyka ma nadal umiarkowane znaczenie $w$ diabetologii, to identyfikacja między innymi mutacji w genach KCNJ11,
$A B C C 8, H N F 1$, glukokinazy, leucyny czy polimorfizmów genu MTNR1B odgrywa nieocenioną rolę w diagnostyce i skutecznym leczeniu coraz szerszej grupy chorych na cukrzycę. Potwierdzenie mutacji w genie KCNJ11 czy $A B C C 8$ pozwala na leczenie pacjentów doustnymi lekami z grupy pochodnych sulfonylomocznika zamiast stosowania uciążliwych iniekcji z insuliny.

W trakcie kursu podczas minisesji plakatowej niektórzy z uczestników prezentowali tezy i wstępne wyniki swoich bardzo ciekawych badań naukowych w zakresie diabetologii. W moim najgłębszym przekonaniu Diabetes Research School to wspaniała platforma wymiany doświadczeń i pomysłów badawczych, umożliwiająca nawiązanie wielu międzynarodowych kontaktów.

\section{Podziękowania}

Składam gorące podziękowania opiekunowi mojej specjalizacji i doktoratu Panu Profesorowi Józefowi Drzewoskiemu za zainspirowanie mnie tematyką kursu i umożliwienie wyjazdu na Diabetes Research School. 
